\title{
MATUTE CREEK, CARTAGENA, COLOMBIA: DETERIORATION OF WATER QUALITY BY HUMAN IMPACT
}

\section{ARROYO MATUTE, CARTAGENA, COLOMBIA: DETERIORO DE LA CALIDAD DEL AGUA POR IMPACTO HUMANO}

\author{
Alonso Marrugo-González ${ }^{1}$, Roberto Fernández-Maestre ${ }^{2}$ \\ ${ }^{1}$ Químico, Magister y Doctor en Química, Programa de Química. Universidad de Cartagena, Campus de San Pablo, Cartagena \\ - Bolívar, Colombia, e-mail: amarrugog1@unicartagena.edu.co; ${ }^{2}$ Licenciado en Química, Magister en Química y Doctor en \\ Química Analítica, Programa de Química. Universidad de Cartagena, Campus de San Pablo, Cartagena - Bolívar, Colombia, \\ e-mail: rfernandezm@unicartagena.edu.co (Corresponding autor)
}

Rev. U.D.C.A Act. \& Div. Cient. 20(1): 209-214, Enero-Junio, 2017

\section{INTRODUCTION}

Matute Creek, Arroyo Matute, rises in Loma de Piedra, northwest of Turbaco City, Bolivar, Colombia, and flows northwest. The river basin has $1594 \mathrm{ha}$, a length of $9.7 \mathrm{~km}$ and ends through the Chupundún and Calicanto channels in the Cienaga de la Virgen, Cartagena (Calderón \& Suarez, 2006). Arroyo Matute was the first aqueduct that supplied Cartagena (Colombia) and worked from 1907-1940; currently, the upper part of the river is an important source of water used in swimming pools and agricultural activities.

The creek has been under anthropogenic pressure. Turbaco lacks an adequate sewerage, and sewage is mainly done through non-waterproofed septic tanks polluting the ground waters that supplies this stream. Moreover, the low coverage of the aqueduct, has prompted people to groundwater reservoirs built without technical criteria that, being abandoned, are used to eliminate waste of all kinds, which also pollute the creek. The high riverbed is a source of water for farming and touristic pools but its flow rate has been reduced by agricultural activities that concentrate contaminants. From its middle part, Matute is used as household waste and garbage receiver in Cartagena (Figure 1) and floods several substandard neighborhoods of this city in the rainy season (Figure 1) where the river spreads diseases transmitted by insects and rodents. In this research, the waters of Arroyo Matute were evaluated by physicochemical and organoleptic analyses. This Report is important because establishes a baseline to compare with future studies in this creek, to monitor its deterioration and to alert the environmental authorities.

\section{MATERIALS AND METHODS}

Sampling Five sampling stations were established:

- Station A, Los Lagos, the river source $10^{\circ} 20^{\prime} 58^{\prime \prime} \mathrm{N}$; $75^{\circ} 25^{\prime} 49^{\prime \prime O}$ (Reference Station) where the water is expected to be less contaminated.

- Station B, Hacienda Matute, $10^{\circ} 20^{\prime} 58^{\prime \prime} N$; $75^{\circ} 25^{\prime} 57^{\prime \prime O}$, middle reach.

- Station C, Hacienda el Cortijo, $10^{\circ} 22^{\prime} 00^{\prime \prime} \mathrm{N} ; 7^{\circ} 27^{\prime} 00^{\prime \prime O}$, middle reach.

- Station D, San Buenaventura University, $10^{\circ} 23^{\prime} 16^{\prime \prime} N$; 75'27’56"O, low reach.

- Station E, Las Palmeras neighborhood, $10^{\circ} 24^{\prime} 05^{\prime \prime} \mathrm{N}$; $75^{\circ} 28^{\prime} 25^{\prime \prime} O$, low reach.

Stations D and E were in the urban area of Cartagena, where most pollution was expected. Physical and chemical indicators of contamination were used: $\mathrm{pH}$; concentration of $\mathrm{NO}_{2}{ }^{-}, \mathrm{NH}_{4}{ }^{+}$and $\mathrm{NO}_{3}{ }^{-}$, and biochemical oxygen demand (BOD). Samplings were conducted in the rainy, September 1999, and in the dry seasons, February 2000. At each station, specific surface water samples were collected and analyzed in triplicate by standard methods (APHA, 2016). Average monthly precipitation was provided by IDEAM (2016). Samples were taken from the water surface up to $1 \mathrm{~m}$ deep, stored in plastic or glass bottles, depending on the analytical requirements, and kept at $4^{\circ} \mathrm{C}$. In the laboratory, samples were analyzed immediately or frozen until analysis, while not exceeding two days.

Methods. The tests were from Standard Methods for the Examination of Water and Wastewater (ASTM): Hardness (2340 C, Volumetric EDTA), alkalinity (2320 B, Titration), 


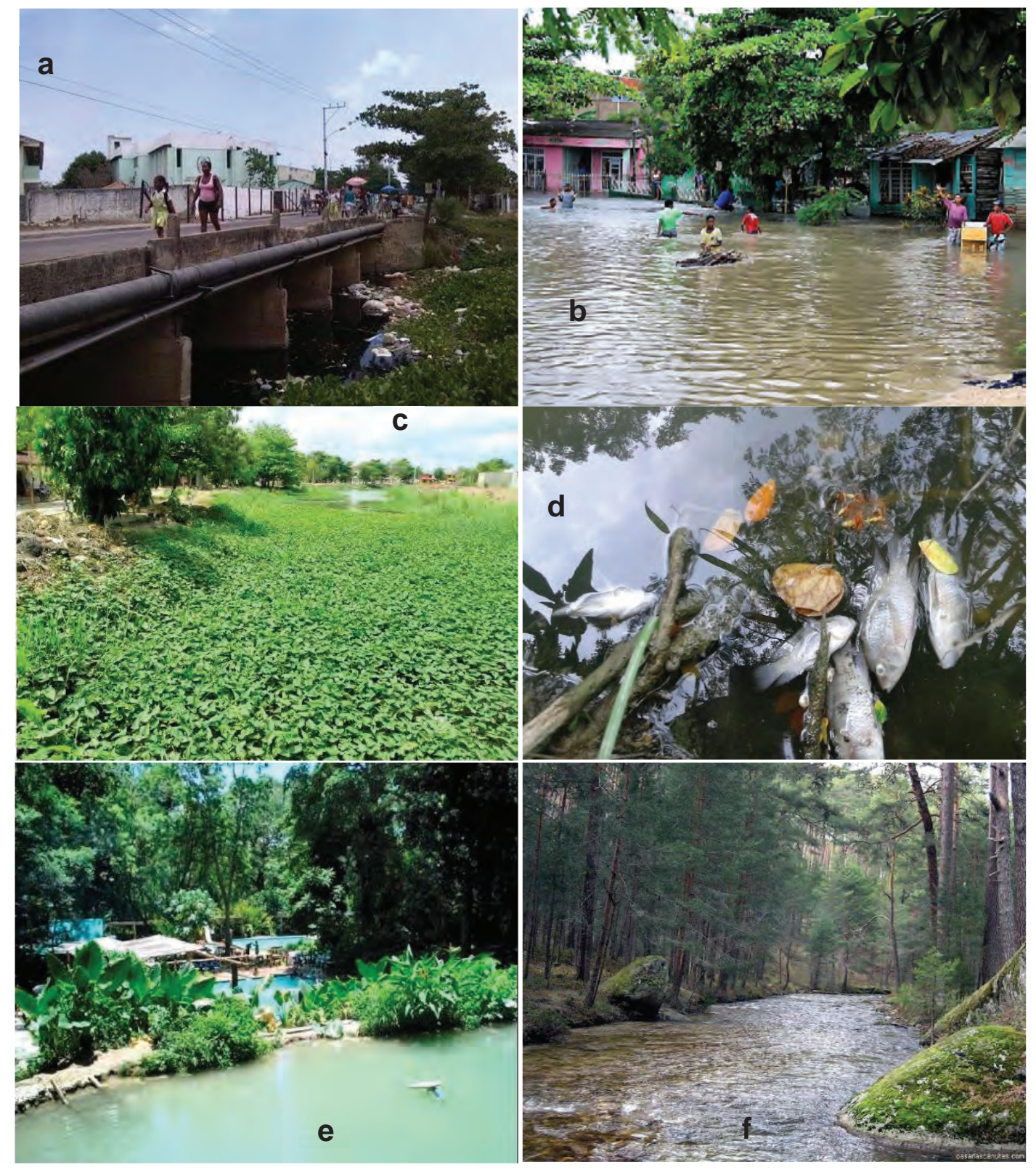

Figure 1. (a) Garbage in Arroyo Matute, station E; (b) Flooding caused by Arroyo Matute by station E; (c) Eutrophication in station E; (d) Fish Kill in station E; (e) Station B; (f) Station C. In internet. [Accessed 11/02/17] from the newspaper El Universal, Cartagena Colombia, except (f) from Alcaldía de Turbaco - Bolívar, Nuestro Municipio, Turismo. http://www. turbaco-bolivar.gov.co/turismo.shtml

a) http://ciudadano.eluniversal.com.co/sites/default/files/imagecache/550x400/maguilera/18-06-2014/puente_de_la_pedro_ romero_-_arroyo_matute_-_reinaldo_manjarre.jpgEimgrefurl 16/09/2015 b) http://www.eluniversal.com.co/cartagena/ local/\% $\overline{\mathrm{C}} 2 \% \mathrm{~A} 1$ inundacion-historica-49238, 04/08/2009. c) http://ciudadano.eluniversal.com.co/problemas-comunitarios/ nada-que-lo-limpian.html. d) http://www.eluniversal.com.co/cartagena/epa-investiga-causas-de-mortandad-de-peces-encano-matute-en-ternera-205143 08/09/2015. e) http://www.eluniversal.com.co/cartagena/rutas-del-encanto/conozca-elparaiso. 04/08/2009 
chloride (4500- $\mathrm{Cl}^{-} \mathrm{C}$, Mercuric nitrate), total solids (2540 $\mathrm{B}$, Total solids dried at $\left.103-105^{\circ} \mathrm{C}\right)$, dissolved solids $(2540$ $\mathrm{C}$, Total dissolved solids dried at $180^{\circ} \mathrm{C}$ ), suspended solids (2540 D, Total suspended solids dried at $103-105^{\circ} \mathrm{C}$ ), oils and fats (5520 B, Partition gravimetric), BOD (5210 B. BOD), chemical oxygen demand (COD) (5220 C, closed reflux titrimetric method), phosphates (4500-PE, ascorbic acid), nitrates (4500 E, cadmium reduction), nitrites (4500 B, colorimetric), ammonium (4500 D, indophenol), and sulfates (4500-SO 4 D, turbidimetric).

Data processing. Statgraphics (Statistical Graphics System) was used; statistical significance tests were held at the $95 \%$ confidence level to determine differences between stations and the reference site or between the seasons. Results were reported as the mean of triplicate analyses and those with RSD $>20 \%$ were rejected. Correlations ( $r$ ) were calculated for each parameter to obtain the trend over the course of the stream. Results were compared to quality criteria for natural waters as defined in national or international legislation aimed to flora and fauna preservation (Minsalud, 2016; WHO, 2008).

\section{RESULTS AND DISCUSSION}

Significant differences were found in physicochemical parameters with the reference station in both seasons (Table $1)$ and also between stations $(p<0.05)$ in most cases. Alkalinity, primarily determined by carbonate $\left(\mathrm{CO}_{3}{ }^{2-}\right)$ and bicarbonate $\left(\mathrm{HCO}_{3}{ }^{-}\right)$content, is important because acts as a pH stabilizer (Patil et al. 2012) and determines the acceptability of a water for irrigation (WHO, 2008). In all seasons, alkalinity exceeded the maximum permissible levels (MPL), indicating high concentrations of carbonates due to the type of soil the stream crosses, a mass of coral limestone resting on a clay stratum (Berna \& Orjuela, 1992).

Water hardness has a natural character and also corresponds to the washing of the soil. The harder the water, the higher the cost to prepare it for its use; a hardness of 80 to $100 \mathrm{mg} / \mathrm{L}$ can be considered satisfactory. In all stations and seasons, the waters were of acceptable quality although hardness exceeded all MPL (WHO, 2008). The concentration of chlorides increased with the distance from the source. The high chloride content in station E may be due to sewage contamination, the influence of seawater by the low height above the sea level and the proximity of the salty Cienaga de la Virgen. BOD is important because it determines the oxygen required to oxidize organic matter by biological means. BOD increased with the distance from the source, without exceeding the MPL established by WHO, consistent with the deterioration of the river water when approaching the mouth. COD indicates the organic matter content and the quality of waters, dissolved or suspended. COD values, higher than the WHO guidelines, also increased with the proximity of the stream mouth indicating anthropogenic pollution; COD's MPL were exceeded in the rainy season, and in both seasons in stations $\mathrm{D}$ and $\mathrm{E}$.

The solubility of dissolved oxygen (DO) in water depends on the temperature, atmospheric pressure, salinity, presence of vegetation, oxidizable organic materials, organisms and aerobes, and disturbance of the interface by wind, fats, hydrocarbons and detergents. Up to $5.5 \mathrm{mg} / \mathrm{L} \mathrm{DO}$ there is a slight impairment of aquatic life, that turns moderate up to 5.0, and severe up to 4.5 (CWT, 2004). DO in Arroyo Matute became harmful to aquatic life during the dry season in the Cartagena urban area and showed a tendency to decrease with the distance from the source. This is possibly due to eutrophication and oxidizable organic matter by the dumping of waste and may have caused recent fish kills (Figure 1). In the rainy season, DO was high in all stations, likely because of the turbulence of the stream and the surface stirring with rain.

The total solids concentration indicates the amount of suspended solids that may seep up through a membrane of 2.0 microns pores. Suspended solids can be separated by mechanical means such as filtration or centrifugation. High solids content prevents penetration of light, reduces dissolved oxygen and limits the development of aquatic life. Terrain features, a mass of limestone coral (Berna \& Orjuela, 1992), justify the high solids content. Suspended solids increased towards the river mouth because more solids from the bottom and banks are expected to be removed and more solids are received from runoff.

Oils and fats tend to float over the waters and hinder the dissolution of oxygen. The concentration of oils and fats exceeded the MPL; this would be associated with activities like washing motor vehicles near the stream banks and nearby petrol stations. Phosphates are essential nutrients to living organisms. They enter natural waters from the runoff of soils, and agricultural, industrial and domestic effluents. Phosphates produce eutrophication, which reduces dissolved oxygen threatening aquatic animals. Phosphates decreased, as expected, towards the river mouth and positively correlated with the eutrophication in stations D and E, where MPL were exceeded.

Nitrites in water could be the result of incomplete nitrification of ammonia. Except for two values, nitrite concentrations in Matute did not exceed the MPL and increased away from the source; this suggests anthropogenic pollution, such as high use of fertilizers and anaerobic conditions. High concentrations of nitrates in the rainy season were potentially due to this season's large amounts of atmospheric nitrogen oxidized into $\mathrm{N}_{2} \mathrm{O}_{5}$, which forms nitric acid, carried down by rain, forming nitrates (Fisher et al. 2007). Because station A 
Table 1. Physicochemical parameters in $\mathrm{mg} / \mathrm{L}$ and field data measured in situ (weather, air and water temperature, $\mathrm{pH}$ and conductivity), in the waters of Arroyo Matute.

\begin{tabular}{|c|c|c|c|c|c|c|c|}
\hline Station & Season & A & B & C & D & $\mathrm{E}$ & MPL \\
\hline \multirow{2}{*}{ Alkalinity } & $\mathrm{R}$ & 299 & 255 & 519 & 366 & 241 & \multirow{2}{*}{$100^{a}$} \\
\hline & $\mathrm{D}$ & 292 & 247 & 223 & 436 & 229 & \\
\hline \multirow{2}{*}{ Hardness } & $\mathrm{R}$ & 292 & 219 & 286 & 280 & 321 & \multirow{2}{*}{$160^{\mathrm{a}}$} \\
\hline & $\mathrm{D}$ & 266 & 226 & 235 & 238 & 303 & \\
\hline \multirow{2}{*}{ Chloride } & $\mathrm{R}$ & 24.1 & 26.8 & 51.4 & 85.4 & 196 & \multirow{2}{*}{$250^{a}$} \\
\hline & $\mathrm{D}$ & 19.3 & 21.3 & 28.7 & 46.6 & 177 & \\
\hline \multirow{2}{*}{$\mathrm{BOD}_{5}$} & $\mathrm{R}$ & 1.92 & 0.16 & 2.02 & 5.44 & 2.03 & \multirow{2}{*}{$6^{2}$} \\
\hline & $\mathrm{D}$ & 1.09 & 2.92 & 3.90 & 4.42 & 1.52 & \\
\hline \multirow{2}{*}{ COD } & $\mathrm{R}$ & 3.6 & 3.3 & 8.4 & 20 & 32 & \multirow{2}{*}{$10^{\mathrm{a}}$} \\
\hline & $\mathrm{D}$ & 16 & 36 & 20 & 52 & 40 & \\
\hline \multirow{2}{*}{ Dissolved oxygen } & $\mathrm{R}$ & 6.40 & 7.68 & 7.52 & 7.36 & 5.12 & \multirow{2}{*}{$>5^{\mathrm{b}}$} \\
\hline & $\mathrm{D}$ & 5.28 & 7.52 & 8.01 & 7.68 & 2.88 & \\
\hline \multirow{2}{*}{ Total Solids } & $\mathrm{R}$ & 558 & 600 & 598 & 674 & 840 & \multirow{2}{*}{$>500^{a}$} \\
\hline & $\mathrm{D}$ & 420 & 421 & 740 & 952 & 959 & \\
\hline \multirow{2}{*}{ Suspended solids } & $\mathrm{R}$ & 238 & 350 & 312 & 360 & 444 & \multirow{2}{*}{-} \\
\hline & $\mathrm{D}$ & 24.3 & 148 & 382 & 454 & 348 & \\
\hline \multirow{2}{*}{ Oils and fats } & $\mathbf{R}$ & 0.978 & 1.13 & 1.53 & 1.54 & 1.53 & \multirow{2}{*}{ Absent** } \\
\hline & D & 2.05 & 3.39 & 0.74 & 1.84 & 2.35 & \\
\hline \multirow{2}{*}{ Phosphates } & $\mathbf{R}$ & 0.005 & 0.007 & 0.043 & 0.255 & 0.316 & \multirow{2}{*}{0.2} \\
\hline & D & 0.019 & 0.019 & 0.009 & 0.293 & 0.264 & \\
\hline \multirow{2}{*}{ Nitrites $\left(\right.$ as $\left.\mathrm{NO}_{2}{ }^{-}\right)$} & $\mathbf{R}$ & 0.002 & 0.009 & 0.015 & 0.086 & 0.135 & \multirow{2}{*}{0.1} \\
\hline & $\mathrm{D}$ & 0.002 & 0.007 & 0.019 & 0.444 & 0.048 & \\
\hline \multirow{2}{*}{ Nitrates } & $\mathbf{R}$ & 8.46 & 7.71 & 4.17 & 1.55 & 1.38 & \multirow{2}{*}{10} \\
\hline & $\mathrm{D}$ & 3.53 & 1.67 & 0.10 & 0.00 & 0.01 & \\
\hline culfato & $\mathrm{R}$ & 6.04 & 7.37 & 36.6 & 55.2 & 67.4 & 100 \\
\hline Sultates & $\mathrm{D}$ & 12.5 & 17.3 & 28.6 & 39.3 & 50.8 & 400 \\
\hline Ammonium (ac $\mathrm{NH}^{+}$ & $\mathrm{R}$ & 0.01 & 0.02 & 0.03 & 1.79 & 1.37 & 10 \\
\hline & $\mathrm{D}$ & 0.02 & 0.12 & 0.03 & 1.85 & 1.46 & 1.0 \\
\hline Time* & $\mathrm{R}$ & $11: 40$ & $12: 33$ & $13: 15$ & $13: 45$ & $14: 45$ & \\
\hline Time & $\mathrm{D}$ & $11: 55$ & $12: 40$ & 13:01 & $13: 30$ & $14: 05$ & - \\
\hline Weather 1 & $\mathrm{R}$ & Cloud & Cloud & Cloud & Sun & Sun & \\
\hline Weather & D & Cloud & Cloud & Cloud & Cloud & Sun & - \\
\hline Air temnerature ${ }^{\circ} \mathrm{C}$ & $\mathrm{R}$ & 30.6 & 29.1 & 26.8 & 28.9 & 33.4 & \\
\hline Air temperature, ${ }^{\circ} \mathrm{C}$ & $\mathrm{D}$ & 27.3 & 27.7 & 28.4 & 27.6 & 30.3 & - \\
\hline Whatertemnerature or & $\mathrm{R}$ & 27.6 & 27.8 & 29.7 & 29.5 & 31.1 & 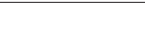 \\
\hline Water temperature, ${ }^{\circ} \mathrm{C}$ & $\mathrm{D}$ & 27.2 & 27.1 & 25.8 & 27.4 & 26.8 & - \\
\hline $\mathrm{nH}$ & $\mathrm{R}$ & 7.3 & 7.9 & 7.9 & 7.8 & 7.7 & $65-9 \Omega^{c}$ \\
\hline pH & $\mathrm{D}$ & 6.6 & 6.9 & 7.2 & 7.3 & 7.1 & $6.5-9.0$ \\
\hline Conductivity $^{2}$ S/cm & $\mathrm{R}$ & 332 & 409 & 141 & 895 & 1038 & $50-1000^{c}$ \\
\hline Conductivity,$\mu \mathrm{S} / \mathrm{cm}$ & $\mathrm{D}$ & 526 & 537 & 586 & 751 & 1736 & $50-1000$ \\
\hline Other & $\mathrm{R}$ & $\mathrm{NO}$ & $\mathrm{T}$ & $\mathrm{T}, \mathrm{St}$ & $\mathrm{T}, \mathrm{G}$ & T,E,SO,G & \\
\hline Other & $\mathrm{D}$ & $\mathrm{NO}$ & $\mathrm{T}$ & $\mathrm{T}, \mathrm{St}$ & $\mathrm{T}, \mathrm{G}$ & $\mathrm{T}, \mathrm{E}, \mathrm{SO}, \mathrm{G}$ & - \\
\hline
\end{tabular}

The reference station is A. ${ }^{a}$ (Minsalud, 2016). ${ }^{b}$ (WHO, 2008). ${ }^{c}(W H O, 2008)$. R: rainy season; D: dry season. MPL: maximum permissible level or recommended levels for drinking water. PL: permissible levels. Cloud: cloudy; Sun: sunny. ${ }^{1}$ at the sampling time. ${ }^{2}$ multiplied by 0.01; T: turbidity; E: eutrophication; SO: strong bad odor; NO: no odor; G: garbage. St: Stagnant waters. * Time when measuring field parameters (weather, temperature, $\mathrm{pH}$ and conductivity). ** Decreto 1594-1984, Colombia, fat/ oil films must be absent for recreational use. 
is a protected area rich in flora and fauna, it shows a relatively high amount of nitrates.

Sulfate ion concentration in natural waters can reach 30 to $50 \mathrm{mg} / \mathrm{L}$ if soils do not contain a significant proportion of sulfate minerals. Sulfate can lead to problems in agriculture and gastrointestinal problems in animals (Burgess et al. 2010). Sulfate concentrations in Matute were below the MPL and increased in both seasons towards the river mouth indicating the stream deterioration for allegedly human activities. Ammonium $\left(\mathrm{NH}_{4}{ }^{+}\right)$also had the same trend. In both seasons, ammonium concentrations in stations $\mathrm{D}$ and E were high, possibly due to organic matter contamination by the inadequate sewerage in the area.

Salinity, conductivity, turbidity, temperature, and $\mathrm{pH}$ were determined in situ, and served as a criterion for determining water quality. International standards indicate that natural waters $\mathrm{pH}$ should be 7.0-8.5; for most aquatic species, the favorable $\mathrm{pH}$ is 6.0-7.2 (WHO, 2008; CWT, 2004). $\mathrm{pH}$ values in the dry season were adequate for aquatic species. The high $\mathrm{pH}$ values in the rainy season in all stations, inadequate for aquatic species, may have been produced by antropogenic factors because the buffering power of water assimilates natural $\mathrm{pH}$ changes. These high $\mathrm{pH}$ values may be due to dissolution of carbonates/bicarbonates by the washing of the coral limestone soil. In addition, high temperatures in the rainy season decrease the solubility of $\mathrm{CO}_{2}$ in water, and this increases $\mathrm{pH}$.

High temperatures in natural waters impair reproduction of aquatic organisms (Miller et al. 2015). The temperature of natural water should be lower than that of air and this was found in all stations, except in C and D in the rainy season, indicating no thermal pollution. Conductivity evaluates the total amount of minerals in water; conductivity variations may come from spills or contaminated waters. Conductivity correlates with temperature, $\mathrm{pH}$, alkalinity, hardness, total solids, total dissolved solids, COD, and chloride in waters; it has been suggested that water quality can be checked by controlling conductivity (Patil et al. 2012). Despite the lack of standards and the effects of the surrounding environment on conductivity, $50-800 \mu \mathrm{S} / \mathrm{cm}$ in tap water and $100-2000$ $\mu \mathrm{S} / \mathrm{cm}$ in fresh water streams can be expected (Fondriest Environmental Inc., 2016). In both seasons, conductivity increased when approaching the mouth of Matute, with a value at station $E$ in the dry season that makes it unsuitable for many uses, including irrigation; in general, the conductivity was also high in the dry season, as expected, due to the concentration of minerals. Finally, the degradation of Matute was evident in stations $\mathrm{D}$ and $\mathrm{E}$ as indicated by turbidity, eutrophication, bad smell, garbage and water stagnation (Figure 1).
The physicochemical characterization of the waters of Arroyo Matute showed that, until 2000, the creek was in good condition as a natural water source up to the middle part of the river. The waters could be used for irrigation or other activities although some parameters exceeded the MPL for drinking water. Significant differences were found between the seasons for nitrates, ammonium, alkalinity, hardness, chloride and COD. The incidence of waste dumping and general deterioration of water was evident in stations $\mathrm{D}$ and $\mathrm{E}$ in the urban area of Cartagena.

Conflicts of interest: The manuscript was prepared and reviewed with the participation of all authors, who declare that there is no conflict of interest that compromise the validity of results. This study was funded with authors' own resources.

\section{BIBLIOGRAPHY}

1. APHA, AWWA (American Water Works Association), and WEF (Water Environment Federation). 2016. Standard Methods For Examination Of Water And Wastewater. 17 Edition. Disponible desde Internet en: https://www.standardmethods.org/ [Accessed in 07/08/16].

2. BERNA, C.O.; ORJUELA, G. 1992. Prospección arqueológica en el municipio de Turbana, departamento de Bolívar. Boletin Arqueol., 3. Presencia eds. Bogota-Colombia. Disponible desde Internet en:

http://publicaciones.banrepcultural.org/index.php/ fian/article/viewFile/5436/5693 [Accessed 07/08/16].

3. BURGESS, B.A.; LOHMANN, K.L.; BLAKLEY, B.R. 2010. Excessive sulfate and poor water quality as a cause of sudden deaths and an outbreak of diarrhea in horses. Can. Vet. J. 51(3):277-282.

4. CALDERÓN, G.; SUAREZ, L. 2006. Caracterización biofísica del Arroyo Matute Turbaco - Bolívar. Teknos 3(1):35-42. Disponible desde Internet en: http://www. eumed.net/eve/resum/07-junio/ccse.htm [Accessed 07/08/16].

5. CLEAN WATER TEAM -CWT-. 2004. Dissolved Oxygen Fact Sheet, FS-3.1.1.0(DO). in: The Clean Water Team Guidance Compendium for Watershed Monitoring and Assessment, Version 2.0. Division of Water Quality, California State Water Resources Control Board (SWRCB), Sacramento, CA. Disponible desde Internet en: http://www. waterboards.ca.gov/water_issues/programs/swamp/ docs/cwt/guidance/3110en.pdf [Accessed 07/08/16]. 
6. FISHER, L.S.; MAYS, P.A.; WYLIE, C.L. 2007. An overview of nitrogen critical loads for policy makers, stakeholders, and industries in the United States. Water Air Soil Poll. 179(1-4):3-18.

7. FONDRIEST ENVIRONMENTAL INC. 2016. Conductivity, Salinity \& Total Dissolved Solids. Disponible desde Internet en: http:/www.fondriest. com/environmental-measurements/parameters/ water-quality/conductivity-salinity-tds/ [Accessed 07/08/16].

8. INSTITUTO DE HIDROLOGÍA, METEOROLOGÍA Y ESTUDIOS AMBIENTALES DE COLOMBIA IDEAM-. 2016. Disponible desde Internet en: http:// www.ideam.gov.co/web/tiempo-y-clima/clima (Accessed 07/08/16).

9. MILLER, G.M.; KROON, F.J.; METCALFE, S.; MUNDAY, P.L. 2015. Temperature is the evil twin: effects of increased temperature and ocean acidification on reproduction in a reef fish. Ecol. Appl. 25(3):603620.
10. MINISTERIO DE SALUD -MINSALUD-. Colombia. 2016. Decreto 1594/84 Chapter IV and Decreto 475/98 Chapter III. Disponible desde Internet en: http:// www.alcaldiabogota.gov.co/sisjur/normas/Norma1. jsp?i=18617 [Accessed 07/08/16].

11. PATIL, P.N.; SAWANT, D.V.; DESHMUKH, R.N. 2012. Physico-chemical parameters for testing of water-A review. Int. J. Environ. Sci., 3(3):1194-1207.

12. WORLD HEALTH ORGANIZATION -WHO-. 2008. Guidelines for drinking-water quality: incorporating 1st and 2nd addenda, Vol. 1, Recommendations. 3 Ed. Geneva. Disponible desde Internet en: http:// www.who.int/water_sanitation_health/dwq/fulltext. pdf [Accessed 07/08/16].

Recibido: Febrero 11 de 2017

Aceptado: Mayo 09 de 2017

Cómo citar:

Marrugo-González, A.; Fernández-Maestre, R. 2017. Matute creek, Cartagena, Colombia: deterioration of water quality by human impact. Rev. U.D.C.A Act. \& Div.Cient.20(1): 209-214. 